\title{
"I'M Not GAY - Not THAT THERE'S ANYTHING WRONG WITH THAT!": ARE UNWANTED IMPUTATIONS OF GAYNESS DEFAMATORY?
}

\author{
Dean R Knight*
}

The question of whether unwanted imputations of gayness are defamatory continues to be controversial. This article considers whether a person can bring a defamation claim if they have been described as being gay or lesbian. In particular, this article addresses whether such an imputation is defamatory, including whether such an imputation tends to lower the reputation of a person in the estimation of "right-thinking" members of society, and the unique issues that this imputation presents for possible defences. In addition to assessing the present position, this article considers whether imputations of gayness ought to be defamatory, particularly in the context of today's legal environment. It is argued that an imputation of gayness should not be treated as being defamatory in the light of the reforms of gay and lesbian rights, including the anti-discrimination and equality protections that are now commonplace in Anglo-Commonwealth societies.

\section{INTRODUCTION}

The quotation in the title of this article is from one of the most well-known Seinfeld episodes, "The Outing". ${ }^{1}$ An eavesdropping reporter mistakenly assumes from the banter between Jerry and George that they are both gay and she subsequently comments on it in an article. Discovering that he and George have been "outed" in newspapers across the country, Jerry is then faced with the difficult task of correcting the gay label attributed to him - with the typical humorous consequences. His flippant humour, however, highlights a much more serious issue. How does the law react when

* Lecturer, Faculty of Law, Victoria University of Wellington. Thanks to the participants at the Sexuality and Citizenship Symposium (Ngaire Naffine, Professor Paula Baron, Nan Seuffert, Elisabeth McDonald and Eddie Clark) for their constructive critique of the paper and useful feedback. Also, thanks to Steven Price, Geoff McLay and Professor Bill Atkin for their comments on various drafts and Jeremy Stewart for research assistance.

1 "Seinfeld" Episode 416, Sony Pictures Digital Inc $<$ http://www.sonypictures.com> (last accessed 23 June 2006). 
a person is incorrectly and/or unwantedly described as gay (or of any other, presumably non-heterosexual, sexual orientation) $?^{2}$ Perhaps more importantly, how should the law react? Although this question arises in the civil courts, the outcome of the question is an important litmus test of the place of gays in society and their citizenship status in today's legal framework.

Discussion of these issues was prevalent in the late 1980s and early 1990s when outing was increasingly used by some gay groups, and in some cases conservative groups, to score political points. ${ }^{3}$ Since that time, there has been a slight shift in the practice; the high-profile outings or dialogue about people's sexuality has moved into the entertainment and sports industries, where the motivation seems to be more of "salacious gossip" rather than strictly political objectives. ${ }^{4}$ Musings about the sexuality of celebrities is common-place in gossip columns and message boards on the internet and in print media. ${ }^{5}$ In line with this trend, there are numerous recent examples of highprofile people anxious to deny suggestions of gayness and to assert their heterosexuality. For example, in New Zealand a famous All Black demanded, and was granted, an apology and donation to a charity from a sports magazine for a reference in an editorial to a rumour that he was gay, despite the editorial criticising the existence of the rumour and clearly challenging its veracity. Later, in an autobiography, he said he was "furious" about the rumour and described the incident as "hurtful". ${ }^{6}$ In another example, Tom Cruise won a default judgment against Chad Slater, also known as wrestling porn star Kyle Bradford, for allegedly telling French magazine Actustar that he had had a gay affair with the actor. ${ }^{7}$ The introduction to Tom Cruise's complaint pleads: ${ }^{8}$

2 Like many writers (for example, Bruce MacDougall Queer Judgments: Homosexuality, Expression, and the Courts in Canada (Toronto: University of Toronto Press, 2000) 13), I have struggled to find a concise, consistent, and appropriate umbrella term to use from the range of different possible labels for sexual orientation. In the end, partly because of my own experience, I have favoured the use of the term "gay" and at times "homosexuality". However, despite the limitations of the terminology, my analysis and themes also generally speak to the full range of "queer" orientations.

3 Andrea Austen and Adrian Alex Wellington "Outing: The Supposed Justifications" (1995) 8 Can J L \& Juris 83. Austen and Wellington assess the objectives of both groups; for straights it is usually "to stigmatize or otherwise socially disadvantage the person outed as a homosexual"; for gays, "it is to advance the cause of gay rights": See Austen and Wellington, above n 3, 85 .

4 Of course, the interest in the sexuality of entertainment and other famous figures may still be tied to political objectives as some people see a relationship between the popular acceptance or "normalization" of gay culture in mainstream society and the progress of any gay rights political agenda.

5 See for example "Datalounge" < http://www.datalounge.com> (last accessed 23 June 2006) (Gossip Forum) and "IHSG? Message Board" <http://www.voy.com> (last accessed 23 June 2006) (the acronym IHSG? stands for Is He or She Gay?). Recently, an online gambling journal, Oddjack, published odds on the next prominent athlete to come out: "Oddjack" < http://www.oddjack.com> (last accessed 23 June 2006).

6 Jeff Wilson Seasons of Gold (Hodder Moa Beckett Publishers, Auckland, 2000) 94-95.

7 Cruise v Slater (20 December 2002) BC249690 (LA Superior Court).

8 Cruise v Slater, above n 7, Complaint for Defamation, para 1. 
To promote his career as an actor in pornographic films, defendant Chad Slater, known professionally as Kyle Bradford, has concocted and spread the completely false story that he had a continuing homosexual affair with Tom Cruise and that this affair was discovered by Mr. Cruise's wife, leading to their divorce. There is not a germ of truth in this vicious, self-promoting story. While Cruise respects others' right to follow their own sexual preference, he is not a homosexual, had no relationship of any kind with Kyle Bradford and does not even know him.

The last sentence of the pleading has a similar theme to Jerry Seinfeld's denial, albeit couched in more careful legalese. More recently, Robbie Williams filed a claim against two magazines which claimed he was gay, a claim which was ultimately settled in his favour. ${ }^{9}$ In addition, two soccer stars and a prominent DJ issued defamation proceedings (as yet unresolved) after a newspaper published claims that they had engaged in a gay orgy. ${ }^{10}$ The list goes on.

The desire to avoid gay labels is not, however, confined to those who deny that they are in fact gay. There are also high profile people who, despite privately acknowledging that they are gay, prefer not to be identified as being so in public. For example, in early 2001 the editor of Out magazine wrote an article asking his then boyfriend, a well-known professional baseball player, to come out. ${ }^{11}$ Over a year later, in a reply also published in Out magazine, the still anonymous sports player lamented that "America is fascinated with sex and secrets, and the idea of a celebrity in men's team sports having a secret - being gay - is simply too enticing not to talk about". ${ }^{12}$ He suggested the issue was not whether baseball was ready for a gay player, but whether the player himself was ready: "I'm not there yet. The road to readiness, both personal and professional, is longer than I expected."13 Although the concern about being identified as gay that underpins defamation claims is therefore not confined solely to straight people, this article generally deals with the situation where the person is inaccurately and unwantedly described as gay, not where the person is accurately but unwantedly described as gay. This distinction arises because the defence of truth will counter a defamation claim for the latter, removing the assumption that the description of gayness is inaccurate. The law's response to the accurate imputations of gayness - outing - is more directly relevant to the law of privacy. The law's reaction to the privacy-outing tension has been thoroughly

9 "Williams wins 'gay' libel damages" (6 December 2005) BBC News $<$ http://news.bbc.co.uk $>$ (last accessed 23 June 2006)

10 "DJ in gay football row to sue News Group" (2 March 2006) The Guardian <http://football.guardian.co.uk> (last accessed 23 June 2006) and "England star sues for libel over gay sex story" (3 March 2006) The Guardian $<$ http://football.guardian.co.uk> (last accessed 23 June 2006).

11 Brendan Lemon "Letter from the Editor" (May 2001) Out New York 15.

12 "Reply" (October 2002) Out New York 83.

13 "Reply", above n 12, 84. 
explored elsewhere and I do not attempt to address it in this article. ${ }^{14}$ However, as there may be some difficulties in relying on the defence of truth in this context, ${ }^{15}$ there remains some blurring of the boundaries between each situation.

In this article, I examine the law's response to unwanted imputations of gayness through the tort of defamation. First, I identify the elements of defamation and the key defences and discuss the unique issues that arise in defamation claims of this kind. Second, I survey the cases in which this claim has been made, identifying the law's historic and present reaction to this issue. Finally, I discuss the courts' evaluation of whether unwanted imputations of gayness are defamatory. In particular, I argue that the outcome of the test reinforces the perceived inferiority of gays and perpetuates homophobic attitudes. I also contend that the courts have placed undue weight on the assumed realist view of the community's attitude towards gays, and that the courts' response is out of step with the ideals and aspirations that underscore recent changes to the societal and legal frameworks of our society.

\section{DEFAMATION: THE BASIC ELEMENTS AND DEFENCES}

\section{A The Basic Elements}

The elements of defamation are simple and well-known. ${ }^{16}$ A person is liable in defamation if: ${ }^{17}$

(a) they publish a statement to a third party;

(b) the statement concerns or refers to another person;

(c) the statement is defamatory (that is, it conveys a defamatory meaning).

The first two elements are generally not contentious and do not raise any unique issues in defamation claims of this kind. The most critical element is the evaluation of whether an imputation of gayness conveys a defamatory meaning. The legal test for determining whether a statement

14 See MacDougall, above n 2 (chapter 5, "Outing", is expanded and updated version of his earlier article "Outing: The Law Reacts to Speech about Homosexuality" (1995) 21 Queen's LJ 79); Austen and Wellington, above n 3; Katheleen Guzman "About Outing: Public Discourse, Private Lives" (1995) 73 Wash ULQ 1531; Larry Gross Contested Closets: The Politics and Ethics of Outing (University of Minnesota Press, Minneapolis, 1993); David Pollack "Forced out of the Closet: Sexual Orientation and the Legal Dilemma of 'Outing"' (1992) 46 U Miami L Rev 711; John P Elwood "Outing, Privacy, and the First Amendment" (1992) 102 Yale LJ 747; Richard Mohr Gay Ideas: Outing and Other Controversies (Beacon Press, Boston, 1992).

15 See Part II B Defence of Truth.

16 In New Zealand the historical labels of libel (written defamation) and slander (oral defamation) have been superseded by the general term "defamation". See the definition in Defamation Act 1992, s 2.

17 Raymond E Brown The Law of Defamation in Canada (Carswell, Toronto, 1987) 9; Philip Lewis (ed) Gatley on Libel and Slander (9 ed, Sweet \& Maxwell, London, 1998) paras 1.3 and 1.4 [Gatley]. 
carries a defamatory imputation has been described in various ways. ${ }^{18}$ The most "popular and [simple], if not more satisfying"19 test, based on the House of Lords approach in Sim v Stretch, ${ }^{20}$ is expressed as a question: ${ }^{21}$

Does the publication tend to lower the reputation of the plaintiff in the estimation of right-thinking members of society generally?

Immediately, the issue becomes obvious. The crucial element is to be assessed by apparently objective community standards - by those "right-thinking" members of society. In the following sections of this article, I go on to consider the track record of this hypothetical person on this issue and explore what the outcome ought to be in the light of today's contemporary, pluralistic society. Before doing so, though, it is necessary to note that two of the available defences raise particular problems in this context, assuming the conclusion that an imputation of gayness is found to be defamatory.

\section{B Defence of Truth}

The defence of truth presents particular difficulties for a defendant. MacDougall, relying on Wick's work, suggests that allegations about homosexuality are often true. ${ }^{22}$ However, he concedes "it will be difficult to prove it of anybody who had not publicly said so", noting that the defence of truth even failed in "so clear a case as that of Liberace". ${ }^{23}$

In general terms, a defendant must prove the truth of every defamatory imputation (including irresistible innuendoes arising from a specific allegation), although it is sufficient that the publication was substantially true. ${ }^{24} \mathrm{~A}$ defendant's justification must meet the "sting" of the

18 Brown, above n 17, 40; John Burrows and Ursula Cheer Media Law in New Zealand (5 ed, Oxford University Press, Oxford, 2005) 11.

19 Brown, above n 17, 43.

20 Sim v Stretch [1936] 2 All ER 1237, 1240 (HL) Lord Atkin.

21 The statement is a simplified version of the one used by Brown, above n 17, 44 (emphasis added). Brown lists 31 other judicial definitions, such as whether the publication "had the tendency to injure... the reputation or character of the plaintiff", "bring him into dispute", cause "him to be shunned or avoided", expose him to "hatred, contempt, and ridicule"; see Brown, above n 17, 40-44. Burrows and Cheer describe four similar formulations: Burrows and Cheer, above n 18, 11. See also Gatley, above n 17, para 1.5.

22 MacDougall, above n 2, 226, citing Ronald F Wick "Out of the Closet and Into the Headlines: 'Outing' and the Private Facts Tort" (1991) 80 Geo LJ 413, 415.

23 MacDougall, above n 2, 226. See the discussion of this case at $\mathrm{n} 54$ below.

24 See Defamation Act 1992, s 8; Brown, above n 17, 360; Gateley, above n 17, para 1.8. 
imputations; a defendant must prove the truth of the pleaded imputation and cannot simply prove the truth of an alternative imputation conveyed by the publication. ${ }^{25}$

In this context, though, the "sting" of a statement may be greater than was intended because defining homosexuality is not straightforward. Most people seem to accept there is a difference between sexual orientation, sexual behaviour, and sexual identity. ${ }^{26}$ These definitional difficulties infiltrate the "sting" of the defamation and any truth defence. Although a publication simply reports a (perhaps one-off) homosexual encounter, it may carry with it the innuendo that the person is gay, or rather, has a homosexual orientation. How then can a defendant prove the truth of the innuendo that a person has a homosexual orientation? Mere proof of a one-off homosexual encounter may be insufficient to meet the innuendo that a person is gay, not straight. Guzman suggests the "either/or nature of truth and falsity invites a startlingly simplistic view of a complex world by suggesting that every defamatory statement is one or the other and by implication, that labels suggest 'facts'." 27 She highlights the ambiguity inherent in the label "homosexual" and reiterates a conclusion reached by Dr West that homosexuality is "fluid". ${ }^{28}$ In a similar theme, MacDougall asks rhetorically: ${ }^{29}$

\footnotetext{
Is the person who lives solely with fantasy and dreams of persons of the same sex any less of a threat to society - that is, any less 'gay' - than someone who regularly engages in sexual activity with a person of the same sex? If what is required to be beyond the pale is actual physical sex with someone of the same sex, what constitutes sex? If Joseph kisses a man or hugs him a moment too long, is this sex? ... Can we call Mrs F a lesbian because she once caressed another woman's breasts?
}

The reference to "fluidity" has similarities with the notion that sexual orientation ought to be viewed in terms of a continuum, rather than in terms of a binary opposition. ${ }^{30}$ Yoshino has rightly described contemporary society's classification of sexual orientation in monosexual terms (namely

25 Haines $v$ Television New Zealand Ltd [2004] NZAR 513, para 44 (HC) Venning J.

26 Terry Stewart Invisible Families: a New Zealand Resource for Parents of Lesbian and Gay Children (Tandem Press, Auckland, 1996) 21. MacDougall assesses that there seems to be an "acceptance of a valid distinction between sexual orientation and sexual activity": MacDougall, above n 2, 26.

27 Guzman, above n 14, 1570.

28 Guzman, above n 14, 1571, fn 185, citing Dr Donald West Homosexuality Re-Examined (University of Minnesota Press, Minneapolis, 1977). Guzman notes that Dr West argues that homosexuality is misapplied or mistakenly deemed applicable to situations where a person had: (1) a fleeting feeling or attraction for a member of the opposite sex; (2) felt an inclination to act; (3) was going through a stage; (4) had changed preferences; (5) had preferences inconsistent with active sexual behaviour; or (6) was ambivalent toward the sex of the partner.

29 MacDougall, above n 2, 26.

30 Most notably, the Kinsey studies spoke of sexuality being depicted on a continuum from exclusive heterosexuality at one end, to exclusive homosexuality at the other: see Alfred C Kinsey, Wardell B Pomeroy and Clyde E Martin Sexual Behavior in the Human Male (W B Saunders Co, Philadelphia, 1948). 
"heterosexual" and "homosexual") as "unstable and naïve" and laments what he describes as the "epistemic contract of bisexual erasure". ${ }^{31}$ This conception of sexuality complicates the endeavour to prove a person's sexuality as a means to resisting a defamation claim. Yoshino's analysis also raises the issue of whether an imputation of bisexuality may, in the eyes of the community, be more damaging than an imputation of (monosexual) gayness. Yoshino contends that bisexuals are marked out for condemnation by both gays and straights, particularly because of perceived "threats" to both groups of monosexuals. ${ }^{32}$

\section{Official or Public Figures and the Qualified Privilege Defence}

As many gay rumours relate to public figures, the public-figure defence or the manifestation of the defence of qualified privilege may be relevant. In some jurisdictions, a defendant can defend a claim if the defamatory statements relate to a public figure and the matter is of public interest, regardless of the truth of the statements. The United States Supreme Court in New York Times Co v Sullivan $^{33}$ ruled that a public official (or public figure) ${ }^{34}$ cannot recover damages for a defamatory falsehood relating to their official conduct unless it is proven that the statement was made with knowledge of its falsity or with reckless disregard for whether it was false or not. The approach had a mixed reception amongst the Anglo-Commonwealth courts, ${ }^{35}$ with variants of the Sullivan approach being recognised in England, ${ }^{36}$ New Zealand ${ }^{37}$ and Australia. ${ }^{38}$ This raises the possibility

31 Kenji Yoshino "The Epistemic Contract of Bisexual Erasure" (2000) 52 Stan L Rev 353, 358.

32 Yoshino says that bisexuality threatens the interests of heterosexuals in ensuring the stability of heterosexuality as the privileged orientation; it also threatens the interests of gays in the stability of homosexuality to the extent that they rely on the "immutability defence" against attacks from critics or as vehicle for political motivation. It also undermines the interests of both in retaining sex as the distinguishing trait in society; straights for the preservation of the present heterosexual societal matrix, gays to justify the creation of (separate) single-sex communities bounded together erotically, socially, and politically. Lastly, bisexuality threatens the interests of monosexuals in defending norms of monogamy. Gays are concerned that the perception that bisexuals are often perceived as "intrinsically nonmonogamous" will undermine their desire to assimilate into mainstream society, while straights are concerned that the "nonmonogamy of bisexuals has been connected to HIV infection, with bisexual 'promiscuity' acting as a bridge (phantasmatically if not actually) between the 'infected' gay population and the 'uninfected' straight population". See Yoshino, above n 31, 362.

33 New York Times Co v Sullivan (1964) 376 US 254 [Sullivan].

34 In the companion case to Sullivan, Curtis Publishing Co v Butts (1967) 388 US 130, the Supreme Court also extended similar protections for speech about "public figures" who achieved status through positive action placing them at the centre of an important matter of public interest.

35 The Supreme Court of Canada has declined to follow this approach. In Hill v Church of Scientology of Toronto [1995] 2 SCR 1130, 1187, Cory J said: "Surely it is not requiring too much of individuals that they ascertain the truth of the allegations they publish."

36 The House of Lords in Reynolds v Times Newspapers Limited [2001] 2 AC 127 (HL) also rejected a specific "political expression" or "public figure" defence but considered that such speech could, on a case by case basis, fall within the ambit of qualified privilege for discussion of other matters of serious public concern. 
that, at least in some jurisdictions, a defendant can respond to a defamation action by arguing that the suggestion of homosexuality related to a public official or figure and was of public or political interest.

The restrictions placed on the scope of the privilege may, however, limit the degree to which this defence can be relied on. The courts still struggle with the notion that, as Virginia Woolf put it, "the public and the private worlds are inseparably connected". ${ }^{39}$ For example, in sentiments consistent with those of other courts, ${ }^{40}$ the New Zealand Court of Appeal warned that expression about a current, former, or aspiring politician's capacity to meet their public responsibility "will depend on a consideration of what is properly a matter of public concern rather than of private concern". ${ }^{41}$ There is at least a distinct possibility that the courts will adopt a slightly amended version of "the state has no place in the bedrooms of the nation" theme. ${ }^{42}$ As a general proposition, there is a powerful argument that a politician's sexuality does not affect their ability to carry out public office and should not fall within the boundaries of protected political expression. The only exception would perhaps be politicians who have taken a conservative moral position on gay issues - one that is arguably more inconsistent with their sexual orientation and/or behaviour. The

37 The New Zealand Court of Appeal, in Lange v Atkinson [2000] 3 NZLR 385 (CA) [Lange (CA)], confirmed (following the invitation of the Privy Council to reconsider its earlier decision in the light of the House of Lords decision in Reynolds $v$ Times Newspapers Limited: see Lange v Atkinson [1998] 3 NZLR 424 (CA) and Lange $v$ Atkinson [2000] 1 NZLR 257 (PC)) its intention to protect political expression - as a category of qualified privilege. The Court limited the protection to "generally published statements which directly concern the functioning of representative and responsible government, including statements about the performance or possible future performance of specific individuals in elected public office": Lange (CA), 390 Judgment for the Court.

38 The High Court of Australia in Lange v Australian Broadcasting Corporation (1997) 189 CLR 520 ruled that qualified privilege exists for the dissemination of information, opinions and arguments concerning government and political matters affecting the people of Australia, subject to the publisher proving reasonableness of conduct. In New Zealand, the defence arises under the rubric "political expression".

39 Virginia Woolf "Three Guineas" reprinted in Morag Shiach (ed) A Room of One's Own and Three Guineas (Oxford University Press, Oxford, 1998) 364.

40 The Sullivan line recognises that protection does not apply unless the criticism of a public official clearly relates to their official conduct or touches on their fitness for office: see Brown, above n 17, 1115. However, the United States Supreme Court has given this a relatively wide interpretation. In Garrision v Louisiana (1964) 379 US 64, 77, Brennan J said:

[A]nything which might touch on an official's fitness for office is relevant. Few personal attributes are more germane to fitness for office than dishonesty, malfeasance, or improper motivation, even though these characteristics may also affect the official's private character.

41 Lange (CA), above n 37, 390 Judgment of the Court.

42 Gordon Donaldson Fifteen Men (Double Day Canada, Toronto, 1969) 84. A voice recording of his statement is available online: CBC News "Indepth Pierre Trudeau" < http://www.cbc.ca> (last accessed 23 June 2006). See $n 127$ below for the famous historical origins of this phrase. 
justification for allowing allegations against politicians in these cases bears some similarity to the hypocrisy-based justifications for outing. ${ }^{43}$

\section{DEFAMATORY MEANING: THE PRESENT POSITION}

\section{A Introduction}

The question of imputations of gayness has arisen in a number of cases throughout the AngloCommonwealth, although the degree of analysis of the issue varies dramatically. History - not all of it old-world - demonstrates that the notional "right-thinking" members of society used to think that being described as gay did lower the reputation of a person in their eyes. On many occasions, the courts have concluded that it is defamatory to be called gay, lesbian, bisexual, homosexual, queer or a sodomite. However, there have been recent indications that the question of whether being called gay is defamatory may be answered differently today. This survey forms the backdrop to the analysis of the "right-thinking" person's evaluation of imputations of gayness.

Before surveying the approach adopted by the courts - or, rather, notionally the right-thinking person - I record a number of important caveats. First, there is a subtle but crucial distinction in defamation cases. The role of the judge is to assess whether the alleged imputations are capable of having a defamatory meaning. Ultimately, it is up to the jury to determine whether in fact the meaning is defamatory. ${ }^{44}$ That point needs to be borne in mind when the courts' historical and present application of the test is considered. Many of the cases in which a written decision has been issued deal with the first, and not the second, question.

Secondly, as the standard depends on contemporary community standards, the recital of previous cases that have held imputations of homosexuality to be defamatory are only of limited value as precedent for today's cases. The words of an English Court over 250 years ago still ring true: "Precedents in actions for words are not of equal authority as in other actions." 45 The Court cautioned that "words which an hundred years ago did not import a slanderous sense now may; and so vice versa." 46 However, the historical treatment and general trends are still of some interest. Similarly, the paucity of these sorts of cases that proceed to trial and then to the law reports obliges me to adopt a broad focus of inquiry. The predominant focus of my analysis is the AngloCommonwealth. As the community standards vary throughout the world, so too may the results of

43 See Austen and Wellington, above n 3, 101.

44 See Defamation Act 1992, s36; Burrows and Cheer, above n 18, 12; Brown, above n 17, 210.

45 Harrison v Thornborough (1714) 88 ER 691, 691 (QB).

46 Harrison $v$ Thornborough, above n 45, 691. 
the right-thinking person test. ${ }^{47}$ Accordingly, I focus my analysis on general themes, rather than tying the analysis to the outcome in any particular jurisdiction.

Ultimately, the question is "one of fact" because whether the statement is defamatory "will vary with the time, the place and the state of public opinion." ${ }^{48}$ With those caveats in mind, however, it is still possible to survey and evaluate the courts' application of the test.

\section{B An Historical Survey of the Right-Thinking Person and Imputations of Gayness}

One of the earliest cases in which this issue arose involved one of the most famous gay figures in history. In 1895, the first of Oscar Wilde's three famous trials was predicated on the basis that the imputation of homosexuality was defamatory. ${ }^{49}$ Oscar Wilde initiated a criminal libel action against Lord Queensbury in respect of a written note that said: "For Oscar Wilde posing as a somdomite [sic]". On the third day of the trial, Wilde's counsel withdrew the prosecution, not because the allegations did not convey a defamatory meaning, but instead because of Lord Queensbury's pleas of justification. Lord Queensbury argued "his resort to 'sodom' mimicked the law and therefore was for the public good". ${ }^{50}$ That is, in his prose, Wilde had violated the law's prohibition against reference to homosexuality and Lord Queensbury had merely "invoked the violence of the name sodomite for the public good". ${ }^{51}$ In modern terms, the publication was justified in the public interest because it exposed Wilde's criminality.

In the mid twentieth century, the issue arose in two English cases. In 1942, the court in Kerr v Kenned $y^{52}$ ruled that allegations of lesbianism amounted to an imputation of unchastity under the statutory regime prohibiting slander against women. When speaking of the plaintiff, another woman had said: "She used to live with other women. She is a lesbian." The statutory regime required the plaintiff to bring the case within one of four statutory categories of slander, the relevant one being slander imputing unchastity or adultery to a woman. Asquith J said: ${ }^{53}$

47 When presented with several similar American cases, a Canadian judge doubted their value in helping him determine the meaning of "blackmail": "[O]ne must exercise great care in seeking aid from such cases, because the peculiar circumstances surrounding them, and the local legislation affecting the question, so often differ them from the like cases here." Macdonald v Mail Printing Co (1900) 32 OR 163, 172 Meredith J.

48 Pulp and Paper Workers of Canada v International Brotherhood of Pulp, Sulphite and Paper Mill Workers (1973) 37 DLR (3d) 687, 699 (BCSC) Rae J.

$49 R$ (Wilde) v Queensbury; see H Montgomery Hyde (ed) The Three Trials of Oscar Wilde (University Books, New York, 1956).

50 Leslie J Moran The Homosexual(ity) of Law (Routledge, London, 1996) 47.

51 Moran, above n 50, 47-48.

52 Kerr v Kennedy [1942] 1 KB 409.

53 Kerr v Kennedy, above n 52, 412-413 Asquith J. 
Can any distinction be drawn on this basis between adultery and fornication, on the one hand, and unnatural relations with other women, on the other, except that the imputation of the latter is, if anything, more wounding, more likely to excite abhorrence on the part of average reasonable people, more likely to spoil the victim's prospects of marriage? ... Almost all [dictionaries] under the term "unchastity", include "impurity," "lasciviousness," and the like. Can anyone doubt that lesbianism is covered by such terms? In my view, the imputation of lesbianism is an imputation of unchastity ... .

In another trial involving a high-profile plaintiff, Liberace successfully sued the Daily Mirror in 1959. ${ }^{54}$ The imputation of gayness arose from an unfavourable review in the Daily Mirror, which included the following extracts: ${ }^{55}$

$\mathrm{He}$ is the summit of sex - the pinnacle of Masculine, Feminine and Neuter. Everything that $\mathrm{He}$, She, or It can ever want. ... They say that this deadly, winking, sniggering, snuggling, chromium-plated, scentimpregnated, luminous, quivering, giggling, fruit-flavoured, mincing, ice-covered heap of mother-love has had the biggest reception and impact on London since Charlie Chaplin arrived at the same station, Waterloo, on September 12, 1921.

As noted earlier, the defence of truth failed after Liberace testified he was not gay and had not engaged in homosexual activity.

In the latter part of the twentieth century, the courts continued to find imputations of gayness were defamatory, although the possible need to review this assumption also began to be foreshadowed. In 1974, the Ontario Court of Appeal ruled, without any analysis, that suggestions that a group of persons were "political homosexuals", amongst other allegations, were "prima facie defamatory". ${ }^{56}$ In 1996, in New Zealand Magazines Ltd v Hadlee, ${ }^{57}$ the New Zealand Court of Appeal accepted that imputations that a woman was lesbian or bisexual were capable of bearing a defamatory meaning. Surprisingly, and rather disappointingly, that conclusion seemed to be conceded by counsel; the main issue in the case was whether the article had in fact conveyed such an imputation. The article in the New Zealand Women's Weekly - entitled "Tell me it isn't true, Anita" - refuted a rumour that Anita McNaught, a television newsreader, was having an affair with Lady Hadlee, the wife of a famous cricketer. ${ }^{58}$ The Court of Appeal ultimately ruled that the

54 Liberace v Daily Mirror Newspapers Ltd (The Times, 18 June 1959). Brown, above n 17, 115, note 1060.

55 Liberace v Daily Mirror Newspapers Ltd, above n 54.

56 Wlodek v Kosko (1974) 7 OR 2d 611 (CA). The remarks were made as part of a series of reciprocal character attacks within a group of Polish engineers and a branch of their industrial Congress, with allegations of communism, phoney qualifications, mental illness, etc.

57 New Zealand Magazines Ltd v Hadlee [2005] NZAR 621 (CA) [Hadlee].

58 The relevant parts of the article "Tell me it isn't true, Anita" in the New Zealand's Women's Weekly said: "It's time to set the record straight and shut up the gossips - Anita McNaught is not having an affair with Sir Richard Hadlee's wife! ... For the record, Anita has never met Karen Hadlee." 
positive denial of any affair did not neutralise the defamatory imputations of lesbianism or bisexuality. ${ }^{59}$ As one judge put it, there is a perception that there is "no smoke without fire"; the "medicine had ... not counteracted all the effects of the poison." 60

In the same year, one member of the New Zealand Court of Appeal suggested that there was a real possibility that "homosexuality or lesbianism might be viewed less seriously now than 20 years ago." ${ }^{61}$ The comment, however, was merely illustrative of the general proposition that perceptions and standards change with time and that reliance on ranges of jury awards in similar defamation cases was of limited value.

The Supreme Court of New South Wales ruled in 1997 that allegations of a homosexual relationship were capable of being defamatory. In Horner v Goulburn City Council, ${ }^{62}$ two city council managers sued in defamation after a performance review contained notes that morale was low in the council because of an "unusual relationship" between the two managers. The plaintiffs argued that those notes, with the other notes, implied a homosexual relationship between the two. On the key question of whether that imputation (if established) was defamatory, Levine J ruled that an imputation of gayness was still capable of being defamatory: 63

Community attitudes to an assertion of a homosexual relationship may range from sympathetic tolerance and understanding to an irrational abhorrence. Whether the former represents a perception from the "ivory tower" and the latter an "avidity for scandal" cannot be concluded. I do not consider that it can conclusively be said that even towards the end of this century's last decade that there can be, among ordinary members of the community, a view that to say of a person that that person is in a homosexual relationship is not disparaging or is not likely to lower that person in the estimation of such people.

In another case concerning Tom Cruise, Cruise v Express Newspapers plc, the English Court of Appeal in 1998 did not disagree with the lower court's ruling that allegations of impotency and homosexuality could still be defamatory. ${ }^{64}$ The Express newspaper had referred, doubtingly, to rumours about difficulties in Tom Cruise and Nicole Kidman's marriage, including suggestions that both of them were gay. ${ }^{65}$ Popplewell $\mathrm{J}$ rejected arguments that such allegations were not defamatory: ${ }^{66}$

59 Two of the three judges (Henry and Barker JJ) also ruled that, despite the denial of any affair, the article was still capable of conveying the defamatory suggestion of an affair.

60 Hadlee, above n 57, 628 Blanchard J.

61 Television New Zealand Ltd v Quinn [1996] 3 NZLR 24, 60 (CA) McGechan J.

62 Horner v Goulburn City Council (1997) NSW LEXIS 2220 (NSWSC).

63 Horner v Goulburn City Council, above n 62, 2225 Levine J.

65 The critical extract, for this allegation, was as follows: 
[I]n any event, it may well be that to say he was impotent or he was gay and she was gay is not of itself defamatory. I do not, I am afraid, accept that. It seems to me that it is capable of having a defamatory meaning.

In the same year, the Ontario Court of Justice in Anderson v Kocsis accepted that being described as "queer" was capable of being defamatory. ${ }^{67}$ A paper sign that read "R. Anderson is a queer, steroid-using cop of the Niagara Regional Police Farce [sic]" was affixed to the rear of a vehicle during a string of acrimonious exchanges between a police officer and a member of the public after the police officer pulled over the defendant's wife. The police officer sued the owner of the vehicle in defamation. Kovas J rejected an argument that the term "queer" was used in the sense of "queer as a 3 dollar bill", that is, meaning strange, odd, or eccentric, ${ }^{68}$ and ruled that the term was defamatory: ${ }^{69}$

I find the meaning of "queer" in its ordinary meaning in these circumstances was a libel. ... The latter part of the dictionary definition of "queer" is a reference to a person's sexual orientation in a pejorative way and is a term designed to expose a person to hatred, contempt or ridicule when used in the way it was. I find the defendant used the word "queer" in the latter sense.

In the 1999 Scottish case of Quilty $v$ Windsor,${ }^{70}$ an employee of a prison sued an inmate for allegations contained in a letter written to the Deputy Chief Executive of the prison service. The

Since she married himbo hunk Tom Cruise and the couple inaugurated themselves as Hollywood royalty - not difficult when the competition is led by Bruce n' Demi - there has been a persistent trickle of speculation. Their failure to produce offspring (like everyone else in uptown LA, they adopted some poor children) set Hollywood tongues wagging. He was gay, they said; he was impotent; she was gay. The whole marriage thing was no more than a business arrangement, they sniggered, and, most sinister of all, the wedding had been ordered by the Church of Scientology, which was keen to establish the couple as a beacon of clean living and an example to the young.

See Cruise v Express Newspapers plc [1998] EWHC (Civ) 935, para 4 Popplewell J.

66 Cruise v Express Newspapers plc, above n 64, para 9 Popplewell J. Interestingly, the Court of Appeal indicated some disagreement, but not sufficient disagreement to overturn his ruling, with the judge's conclusion that being called a member of the Church of Scientology could be defamatory. Brooke LJ said that "just because some people have very strong views about [the Church], it does not necessarily mean that to say of someone that he is a member of it is capable of being defamatory." He went on to say "[m]uch the same could be said of an allegation that a person is a freemason". See Cruise v Express Newspapers plc, above n 64, 956 Brooke LJ. It seems those comments were deemed not applicable to gays though.

67 Anderson v Kocsis [1998] 86 OTC 107 (OCJ).

68 Kovas $\mathrm{J}$ said even if it was used in that sense, the term still carried a defamatory imputation: Anderson $v$ Kocsis, above n 67, paras 37-39 Kovas J.

69 Anderson v Kocsis, above n 67, para 37-39 Kovas J. The Court also found allegations of steroid use were defamatory and that the defendant was motivated by malice. Separately, the defendant had also been prosecuted and fined for criminal libel.

70 Quilty v Windsor [1999] SLT $346(\mathrm{OH})$. 
letter contained various allegations, including that the employee was gay. Lord Kingarth made obiter comments that allegations of homosexuality per se were not defamatory but still allowed defamatory imputations connected to allegations of homosexuality: ${ }^{71}$

I am inclined to agree with counsel for the first defender that merely to refer to a person as being homosexual would not now generally at least be regarded - if it ever was - as defamatory per se. ...

However ... innuendo ... that his alleged homosexuality was, albeit in some unspecified way, interfering with his work, and thus affecting his fitness to hold office, in the Prison Service, in particular in relation to his dealings with young offenders ... could readily be said to be defamatory.

In doubting that an allegation of gayness per se was defamatory, the Court placed some emphasis on how "[m]atters have so moved on" from the days when homosexuality was a crime. ${ }^{72}$ Specifically, the Court recognised that the law allowed a single man living in a stable gay relationship to adopt a child and afforded the same protection to a gay co-habitee as it afforded to a husband or wife in relation to guarantees given for a partner's debts. ${ }^{73}$ The same issue had arisen earlier in another Scottish case following a satirical television "News Quiz" which allegedly contained the imputation that a prominent nun was a lesbian. ${ }^{74}$ However, in that case the Court declined to rule, for procedural reasons, on whether a "suggestion of lesbianism remains defamatory these days." 75

71 Quilty $v$ Windsor, above n 70, para 20 Lord Kingarth.

72 Quilty $v$ Windsor, above n 70, para 6 Lord Kingarth.

73 Quilty v Windsor, above n 70, para 6 Lord Kingarth.

74 Prophit $v$ British Broadcasting Corporation [1997] SLT $745(\mathrm{OH})$ [Prophit]. The alleged defamatory passage in the broadcast was as follows:

$\begin{array}{ll}\text { Presenter: } & \text { 'Allan, How did Penny profit after coming under Holy Orders?' } \\ \text { Panellist: } & \text { 'Is this a Nun?' } \\ \text { Presenter: } & \text { 'It is a Nun.' } \\ \text { Panellist: } & \text { 'Wasn't hard was it? Lesbian? Lesbian Nun. I'm not doing that. I have a } \\ & \text { prurient Welshman here who's got a Lesbian Nun story. I don't know about } \\ & \text { this.' } \\ \text { 2nd Panellist: } & \text { 'She was called Penny. She was an American lady. I can't remember much } \\ & \text { more about her except her picture. She's not been up to anything with Clinton } \\ \text { has she?' } & \text { 'No, no.' } \\ \text { 1st Panellist: } & \text { 'and every other woman in America. He's probably getting through the Lesbian } \\ & \text { Nuns now.' } \\ \text { Presenter: } & \text { 'Let me tell you. Let me put you out of your misery. This is Sister Penny } \\ & \text { Prophit an unqualified Franciscan Nun who was given L850,000 in Nursing } \\ & \text { Research Grants before being exposed as a fraud. Along with her colleagues, } \\ & \text { Father Huge Con and Mother Superior Fibber'. }\end{array}$

Prophit, above n 74, 745 Judge Coutts.

Prophit, above n 74, 748 Judge Coutts. 
In this same era, two Canadian cases considered imputations of gayness arising from pejorative name-calling. However, in both cases the analysis was grounded in the jocular nature of the insults, rather than considerations of whether the imputations themselves were defamatory. The Ontario District Court in Culhane v Rawlings ${ }^{76}$ refused to allow a claim that the plaintiff's supervisor, in the presence of a number of his fellow Ford Motor employees, defamed him by calling him "a son of a bitch" and, as the judge characterised it euphemistically, "a male person who performed homosexual acts. ${ }^{77}$ McCart DCJ said: ${ }^{78}$

If I had one dollar for every time I heard either of those expressions during some three years in the armed forces and at summer jobs while attending university and law school, I would have been financially independent by the time I was 25 years old. Their use is so commonplace as to be virtually incapable of constituting defamation. In some perverse way they seem to be used as expressions of friendship.

However, McCart DCJ did not strike out the action because he accepted, without any discussion, that the insinuation could still have diminished or destroyed the plaintiff's reputation or character in the eyes of his fellow workers. ${ }^{79}$ In contrast, Matheson $\mathrm{J}$ in Bell $v$ Intertan Canada Ltd $^{80}$ rejected a claim of defamation where workers described a colleague as "gay" or a "fag". Bell had been working at the RadioShack and alleged that the store manager, assistant manager and other employees would call him names, including on occasions referring to him as being "gay" or a "fag". He said: ${ }^{81}$

[They] began to refer to me as being 'gay' and a 'fag'. I objected but my objections were ignored. Mr. Patmore and Mr. Johnson didn't do anything to stop it. This caused further emotional stress on me. They were saying that I was a homosexual. While I have nothing against homosexuals, I don't want to be called one either.

However, the defendants characterised these incidents as "name calling" and teasing which was done in "a friendly, joking manner." 82 Matheson J's reasons were brief and focused solely on the jocular nature of the remarks rather than on whether they diminished the plaintiff's reputation. ${ }^{83}$

76 Culhane v Rawlings (1987) 6 ACWS (3d) 423 (DC).

77 Culhane v Rawlings, above n 76, para 2 McCart DCJ.

78 Culhane v Rawlings, above n 76, para 2 McCart DCJ.

79 Culhane v Rawlings, above n 76, para 3 McCart DCJ.

80 Bell v Intertan Canada Ltd [2002] SKQB 446 (QB, Sask).

81 Bell v Intertan Canada Ltd, above n 80, para 23 Matheson J.

82 Bell v Intertan Canada Ltd, above n 80, para 27 Matheson J. The defendants also relied on "horse play" between the employees including when, apparently jokingly, the plaintiff had "offered to stick his finger up 
The most significant developments occurred after the turn of the millennium as the courts began to more explicitly confront the changes to societal views and aspirations. In 2001 the New South Wales Supreme Court ruled that allegations of homosexuality per se could not be defamatory. In Rivkin v Amalgamated Television Services Pty Limited, ${ }^{84}$ Rene Rivkin sued a television station after an investigative programme suggested that he had had "homosexual intercourse" with his male driver and that he was involved in the death of his driver's female partner. The television programme was about the death of a young model, Caroline Byrne. The inquest was said to have made a number of adverse credibility findings about Byrne's partner, Gordon Wood. The programme suggested Byrne was murdered and, it was argued, implied that Wood was suspected of having murdered her. Wood was the driver for Rivkin and subsequently his personal assistant. The programme suggested that Byrne had been "suspicious" about Wood's relationship with Rivkin and that she had "sprung" them having homosexual intercourse. Rivkin also argued that the programme had suggested that he was criminally liable for Byrne's death or had behaved in such a way as to warrant the well deserved suspicion that he was criminally liable for her death.

The television station argued that allegations of homosexuality per se were not capable of being defamatory of the plaintiff. Bell J accepted the argument. She noted that it was not sufficient that the assertion "would disparage an individual in the eyes of a section of the community ... unless the views of that group happened to correspond with those of right thinking members of the society generally." ${ }^{85}$ However, she pointed to a general change in the social and moral standards of the community. Particular weight was put on the framework of legislation, both at a state and federal level in Australia, which reflected a change in community attitudes. ${ }^{86}$ Importantly, though, Bell J

my rectum in order to give me an erection and, on another occasion, he put his hands on my zipper and got down on his knees in front of me": Bell v Intertan Canada Ltd, above n 80, paras 28-29 Matheson J.

83 Bell v Intertan Canada Ltd, above n 80, para 30, Matheson J said:

After considering all of the testimony relating to the "name calling", it is impossible to conclude other than that the various individuals called each other, on occasion, names which might appear to many to be objectionable, but in the context in which the name calling arose it is clear that it was all done in jest. Thus, there were no actionable defamatory statements.

84 Rivkin v Amalgamated Television Services Pty Limited [2001] NSWSC 432 [Rivkin v Amalgamated Television].

85 Rivkin v Amalgamated Television, above n 84, para 17 Bell J.

The defendant highlighted a range of legislation supporting this point:

(a) the abolition of the proscription of homosexual conduct between consenting male adults in 1984;

(b) the provisions of the Anti-Discrimination Act 1977 which renders it unlawful to discriminate against a person on the grounds of homosexuality in a wide range of contexts including employment, the provision of goods and services and education; 
did not consider that these legal reforms were determinative of a change to "the common standards held by the hypothetical audience"; instead, she said that the framework "spoke strongly" of a change in social and moral values. ${ }^{87}$ In fact, she accepted that "reasonable members of the community by reason of religious belief may think less of a man who engages in homosexual intercourse", ${ }^{88}$ but did not consider that this was reflective of the views of the hypothetical "rightthinking" members of society.

However, Bell $\mathrm{J}$ did not throw out the allegations in their entirety. She ruled that assertions that a man is a homosexual may still give rise to defamatory imputations "such as hypocrisy, the abuse of a position of power or trust, infidelity, or the like". ${ }^{89}$ Bell $\mathrm{J}$ allowed the plaintiff to amend the pleaded defamatory imputations to encapsulate the following allegation: 90

[T]he plaintiff, a wealthy, middle aged man, had used his position of relative power (he being the employer of Mr Wood, a younger man engaged as his chauffeur) and wealth to procure Mr Wood's sexual service by lavishing gifts upon him.

In another claim involving the same plaintiff and arising from similar allegations, the issue was touched on by the High Court of Australia in John Fairfax Publications Pty Ltd v Rivkin..$^{91}$ One of the alleged defamatory imputations was that Mr Rivkin had engaged in "homosexual intercourse" with his personal assistant or that, in the context of their murder investigation, the police suspected

(c) the Anti-Discrimination (Homosexual Vilification) Amendment Act 1993 which inserted a provision into the Anti-Discrimination Act making it unlawful, by a public act, to incite hatred towards, serious contempt for or severe ridicule of a person upon the grounds of homosexuality;

(d) the Property (Relationships) Legislation Amendment Act 1999 which amended the De Facto Relations Act 1984 (now the Property Relations Act 1984) to broaden the definition of "de facto relationship" so as to include homosexual relationships;

(e) the Migration Act 1958 with the provision made in the Regulations thereunder for the issue of visas to permit the entry into Australia of persons who are in interdependent relationships, including homosexual relationships;

(f) the objects of the Workplace Relations Act 1996 which include eliminating discrimination upon the basis of sexual preference.

Rivkin v Amalgamated Television, above n 84, paras 19-20 Bell J.

Rivkin v Amalgamated Television, above n 84, para 30 Bell J.

88 Rivkin v Amalgamated Television, above n 84, para 26 Bell J.

Rivkin v Amalgamated Television, above n 84, para 30 Bell J.

90 Rivkin v Amalgamated Television, above n 84, para 32 Bell J.

91 John Fairfax Publications Pty Ltd v Rivkin (2003) 201 ALR 77 (HCA) [John Fairfax v Rivkin]. 
that Mr Rivkin had engaged in such "homosexual intercourse" with his assistant. ${ }^{92}$ The issue of whether such allegations were defamatory was not directly considered by the courts because the jury found that the alleged imputations were not implied by the publications and therefore the question did not arise. However, in an (ultimately successful) appeal against the unreasonableness of the jury's finding on this point, one member of the High Court of Australia made obiter observations that these imputations could still be defamatory. Kirby J said: ${ }^{93}$

The homosexual intercourse imputations: In most circumstances, it ought not to be the case in Australia that to publish a statement that one adult was involved in consenting, private homosexual activity with another adult involves a defamatory imputation. But whether it does or does not harm a person's reputation to publish such an imputation is related to time, personality and circumstance. Once, it was highly defamatory in many countries to allege, or suggest, that a person was a communist. Now, in most circumstances, it would be a matter of complete indifference. The day may come when, to accuse an adult of consenting homosexual activity is likewise generally a matter of indifference. However, it would ignore the reality of contemporary Australian society to say that that day has arrived for all purposes and all people. At least for people who treat their sexuality as private or secret, or people who have presented themselves as having a different sexual orientation, such an imputation could, depending on the circumstances, still sometimes be defamatory.

Ultimately, however, this issue did not need to be resolved because the proceedings were settled before a retrial took place. ${ }^{94}$

Soon after the Rivkin litigation, another New South Wales judge declined to follow Bell J's conclusion in Rivkin $v$ Amalgamated Television that imputations of gayness per se were not defamatory. In Kelly $v$ Fairfax Publications Ltd, the plaintiff issued defamation proceedings after a newspaper published a photo and an article that suggested that he would be participating in a bondage display at Sydney's Gay and Lesbian Mardi Gras. ${ }^{95}$ The plaintiff described himself as a "happily married heterosexual" and claimed the publication imputed, amongst other things, that he was a homosexual. Rejecting Bell J's conclusion in Rivkin v Amalgamated Television, Levine J ruled that this imputation was capable of being defamatory. ${ }^{96}$ Little if any explanation was given for arriving at a different conclusion. Levine J said: "Whilst affording Bell J's decision utmost respect, I

92 There were also numerous allegedly defamatory statements about some involvement in the murder of his personal assistant's partner.

93 John Fairfax $v$ Rivkin, above n 91, para 140 Kirby J. The other members of the High Court of Australia confined their discussion to the reasonableness of the jury's conclusion on the imputation issue and did not address whether the imputation was defamatory.

See Rivkin v John Fairfax Publications Pty Ltd [2004] NSWSC 671.

95 Kelly v Fairfax Publications Ltd [2003] NSWSC 586 [Kelly].

Kelly, above n 95, 40 Levine J. 
do not propose to follow it and cannot say that in any event I would be entirely in agreement with it." 97 Notably, Levine $\mathrm{J}$ appeared to doubt the impact that the presence of anti-discrimination legislation had on the issue, noting that if the general community thought no less of gay people then "there would be no need for all this remedial legislation." 98

\section{DISCUSSION}

\section{A Introduction}

The track record of the right-thinking person demonstrates that they generally viewed imputations of gayness as tarnishing a person's reputation. There has been some softening in the position in recent years with doubts expressed about whether societal and legal changes render this conclusion untenable. Despite these doubts, often expressed in obiter terms, there has been an apparent unwillingness to definitively reject this conclusion. Of particular concern, though, is the shallowness of analysis of this issue or its implications. With one notable exception, Bell J's discussion in Rivkin $v$ Amalgamated Television, ${ }^{99}$ the conclusion that an imputation of gayness tarnishes a person's reputation is made with little, if any, analysis. This notion has been accepted without argument or is made by simple assertion. It is notable that the only case that has considered this reasonably complex question in some detail concluded that such an imputation was not capable of being defamatory.

Even if the more progressive stance of Bell $\mathrm{J}$ in Rivkin $v$ Amalgamated Television was adopted, a distinction still needs to be drawn regarding the nature of the imputation of gayness. Imputations of "gayness per se" are where there is a mere assertion that someone is a homosexual, and "gayness plus" where there is an assertion that someone is a homosexual along with some other related assertion such as infidelity or representational dishonesty. Even if the former is not defamatory, the latter may still be so if the "plus" element is defamatory in its own right. However, this distinction may still prove problematic. It is possible that the same prejudice that underscores the conclusion that imputations of gayness per se are defamatory can still infiltrate the evaluation if the seriousness of the "plus" element effectively restates the allegation of homosexuality, or is coloured and exaggerated by the assertion of homosexuality. ${ }^{100}$ This manner in which the test can still be manipulated is demonstrated by Jason Donovan's successful defamation claim in the early 1990s against a magazine that published a photo of him wearing a shirt emblazoned with the words "Queer

97 Kelly, above n 95, 40 Levine J.

98 Kelly, above n 95, 39 Levine J.

99 Rivkin v Amalgamated Television, above n 84.

100 McNamara contends that these types of allegations hide, "[u]nder the guise of hypocrisy, ... the prejudice and bigotry that identify sexual orientation as a relevant factor upon which a person's moral worth should be judged": Lawrence McNamara "Bigotry, community and the (in)visibility of moral exclusion: homosexuality and the capacity to defame" (2001) MALR 271, 281. 
as Fuck". ${ }^{101}$ Donovan sued, not on the imputation of gayness (which he accepted was not defamatory), but on the imputation that he was "lying and deceitful about his sexuality" because he had previously stated he was not gay. While imputations of dishonesty and hypocrisy may found a claim, the almost irresistible inference is that the claim was in reality about the imputation of gayness, especially as he was ultimately awarded damages of $£ 200,000$. Further, claims of representational dishonesty are problematic because they implicitly adopt a monosexual perspective of sexual orientation and ignore the potential fluidity of sexual orientation.

Bell J's progressive approach has not yet been universally accepted in Australia nor has it yet been considered in other jurisdictions. There remains the prospect of findings that an allegation of gayness lowers a person's reputation in the eyes of right-thinking people. The conclusion that imputations of gayness are defamatory is unsatisfactory in a number of respects and, in my view, ought to be avoided. First, the conclusion marks gay people out as inferior and reinforces homophobic attitudes towards gays. Second, the test has been misapplied to place undue emphasis on actual community views, ignoring the aspirational aspect of the test. Third, the outcome is out of step with today's vision of a contemporary, pluralistic society, highlighted particularly by the numerous reforms that seek to give gays equivalent citizenship rights to those of straights.

\section{$B$ Conclusion Reinforces the Perceived Inferiority of Gays and Homophobic Attitudes}

The conclusion that an imputation of gayness is defamatory carries the necessary - and homophobic - implication that being gay is somehow inferior to being straight. Quite rightly, MacDougall describes this as "ridiculous and offensive". ${ }^{102}$ The effect of the numerous cases that uphold such defamation claims is to mark out gay people as "other" and as forming part of a less desirable class. Gay people are thus grouped with criminals, fraudsters, untruthful people, and the like. ${ }^{103}$ This reinforces the status of gays as second-class citizens and emphasises dominant heterosexist norms and stereotypes. Heterosexuality is equated with "normality, morality, the right to publicity as to orientation, and the right to privacy as to sexual conduct and sexual information", while homosexuality is equated with "deviance, immorality, and no right to be open as to orientation". 104

101 The case was not reported but McNamara has reconstructed aspects of the litigation from news reports: see McNamara, above n 100, 281.

102 MacDougall, above n 2, 226.

103 This same point is made by MacDougall, above n 2, 226-227.

104 Guzman, above n 14, 1599. Her focus, however, is on the unsettling nature of outing and the associated pain for victims persuades her that the realities of damage to reputation should not be ignored. 
Gays are excluded from the morally desirable conception of community. As McNamara notes: ${ }^{105}$

[D] efamation laws play a role in defining the community with (largely implicit) assumptions about who

is included in and who is excluded from the community of ordinary decent folk that are the hypothetical

judges of our moral worth.

This normative process of validating moral standards serves to exclude gays from this community. ${ }^{106}$ Overall, the courts' conclusion that imputations of gayness are defamatory effectively defames gays, perpetuating asserted assumptions that gays are less worthy than straights.

Notably, gays are treated less favourably by right-thinking people than other minority groups. Allegations that a person is a member of an ethnic minority, religious group or political party are not defamatory. ${ }^{107}$ Suggestions of gayness should be "no more defamatory [than] to state falsely that one is ... black when he is white, French when he is Italian, Episcopalian when he is Jewish or Democrat when he is Republican."108 MacDougall doubts that the acceptance that unwanted attributions of ethnicity, race, or religion are not defamatory is based on "community standards of acceptability". ${ }^{109}$ Gays are marginalised and marked out as different, both from the so-called mainstream and from other minority groups, by the inconsistent outcome of this test.

The homophobic outcome of the test also presents implications for litigants. Those seeking to bring defamation actions based on allegations of gayness walk a very fine line. As Jerry Seinfeld was cautious not to condemn gays when he tried to wriggle from underneath the cloak of homosexuality, so too was Tom Cruise when in his pleadings he took great care to try not to cast aspersions on those who "follow their own sexual preference". ${ }^{110}$ Suggestions of homophobia may also adversely affect a person's reputation; accusations of prejudicial attitudes would reflect poorly on a person, both in the eyes of the ordinary public and the right-thinking person. Indeed, allegations of homophobia would seem to fall within the same group of prejudicial imputations, such as racist and "Jew hater", ${ }^{111}$ that if said by another person could found a defamation action. There is a

105 McNamara, above n 100, 274.

106 McNamara, above n 100, 274.

107 Lewis, above n 17, 25.

108 Guzman, above n 14, 1574, repeating the argument of the Globe when sued by Lyle Alzado for false imputations of homosexuality.

109 MacDougall, above n 2, 227. He suggests "a poll of Canadians might [still] find that that they would think less of a person if told she were First Nations or a Jew or black": MacDougall, above n 2, 227.

110 See Part I Introduction.

111 Cherneskey v Armadale Publishers Ltd [1979] 1 SCR 1067; De Stempel v Dunkels [1938] 1 All ER 238 (CA). 
particular irony and intellectual conundrum in that the same test may lead to the conclusion that it is defamatory to be described as both a homosexual and a homophobe!

\section{Misapplication of the Test}

The basic conundrum raised by this issue is a contest between the "idealists" and the "realists". ${ }^{112}$ On the one hand, the realists argue that the test for defamation should simply assess whether a person's reputation has been tarnished and that this requires that the courts reflect society's actual views - regardless of whether they are based on prejudice and homophobia. For example, Guzman suggests that the "determination of whether reputation has been damaged is better answered through fact than wishful fiction." 113 On the other hand, the idealists demand that the test reflect the goals and aims of a contemporary, pluralistic and tolerant society, and argue that the courts should take an aspirational approach to community attitudes - even if this is discordant with reality. Commentators such as McDougall say that even though the bulk of society might find a description as homosexual injurious, the courts should not accept "that bigoted view [or] promote it through laws on defamation". ${ }^{114}$

Although this conundrum is highlighted in the case of imputations of gayness, the realist versus idealist conflict in the right-thinking person test has lead to some criticism of the right-thinking person standard itself. For example, Professor Prosser suggests that the determination of the views of right-thinking people requires the courts to make inappropriate "definitive pronouncement[s] upon whether the views of different segments of the community are right or wrong, sound, or morally justifiable."115 There is also a degree of unreliability when a jury is asked to assess community attitudes, either in a wholly objective or modified, aspirational sense. It can be doubted whether juries are capable of undertaking such an assessment, particularly due to the irresistibility for the jurors to simply apply their own views and values. The inadequacy of reference to an apparent objective assessment of community norms or values is captured by McLachlin CJ (albeit in a different legal context): ${ }^{116}$

On its face, the test was objective, requiring the trier of fact to determine what the community would tolerate. Yet once again, in practice it proved difficult to apply in an objective fashion. How does one

112 Magnusson has previously used these terms in his discussion of the values which underlie defamation law. See Roger S Magnusson "Freedom of speech in Australian defamation law: Ridicule, satire and other challenges" (2001) 9 Torts LJ 269.

113 Guzman, above n 14, 1575.

114 MacDougall, above n 2, 227.

115 W Page Keeton (ed) Prosser and Keeton on the Law of Torts (5 ed, West Publishing, Minnesota, 1984) 777.

$116 R v$ Labaye (2006) 260 DLR (4th) 595, para 18 McLachlin CJ. The point is made in the Supreme Court of Canada's discussion (and ultimate rejection) of a test of obscenity based on community standards of tolerance. 
determine what the "community" would tolerate were it aware of the conduct or material? In a diverse, pluralistic society whose members hold divergent views, who is the "community"? And how can one objectively determine what the community, if one could define it, would tolerate, in the absence of evidence that the community knew of and considered the conduct at issue? In practice, once again, the test tended to function as a proxy for the personal views of expert witnesses, judges and jurors. In the end, the question often came down to what they, as individual members of the community, would tolerate. Judges and jurors were unlikely, human nature being what it is, to see themselves and their beliefs as intolerant. It was far more likely that they would see themselves as reasonable, representative members of the community. The chances of a judge or juror saying, "I view this conduct as indecent but I set that view aside because it is intolerant", were remote indeed. The result was that despite its surficial objectivity, the community standard of tolerance test remained highly subjective in application.

Given the risk of jurors simply applying their own value judgment in these cases, it is therefore regrettable that the courts have been reluctant to settle the question once and for all by determining that such allegations are not capable of being defamatory.

In addition, Prosser argues that the right-thinking test ignores the reality that a person's reputation and relationships with others may be affected by defamatory comments that rightthinking people would not care about. ${ }^{117}$ For example, the example often given by the realists is where someone describes a criminal or a member of the Mafia as "honest". This would not concern the right-thinking person but may be devastating for a criminal or a member of the Mafia. ${ }^{118}$ Prosser, and others, favour the American approach which focuses on whether a person's reputation is lowered in the estimation of a particular group - the group being a substantial and respective, albeit small, minority. ${ }^{119}$ These criticisms focus on the damage caused when a person's reputation is lowered in someone else's eyes, even though the damage is still presumed rather than actual. ${ }^{120}$

Significantly, though, the defamation framework rejects the pleas of the realists for unqualified application of actuality. The right-thinking person test does not adopt a wholly objective standard; it contains, at least, some aspirational element. Although many emphasise that the role of tort law is to "make the injured whole and not to change social mores", ${ }^{121}$ the reality is that defamation law has

117 Keeton, above n 115,777

118 Burrows and Cheer, above n 18, 27.

119 Keeton, above n 115, 777.

$120 \mathrm{McNamara}$ suggests the adoption of this test might be a more realistic, allowing the courts to recognise the countervailing views of sub-communities on this issue and avoiding the problems associated with determining the issue based on the (moral) views of "one monolithic, uniform community": McNamara, above n 100, 290 .

121 Patrice S Arend "Defamation in the Age of Political Correctness: Should a False Public Statement that a Person is Gay be Defamatory?" (1997) 18 N Ill U L Rev 100, 114. 
never provided an unrestricted panacea for injury to reputation. Defamation law consistently recognises public policy factors that prevent the recovery of damages for loss of reputation. Quite apart from the aspirational threshold provided by the right-thinking person standard, a number of the defences such as absolute or qualified privilege, the public official or figure defence, and honest opinion recognise that other countervailing interests favouring free speech may be more important than protecting a person's reputation.

Most of the recent decisions that have continued to find imputations of gayness defamatory have, however, either explicitly or implicitly over-emphasised the litmus test of community opinion favoured by the realists, without consideration of whether this reflects the normative values of rightthinking people. For example, Kirby $\mathrm{J}$ in John Fairfax $v$ Rivkin suggests "the reality of contemporary Australian society" is that people are not yet indifferent to accusations of consensual homosexual activity. ${ }^{122}$ But his remarks beg the question set by the modified objective standard. Do we expect our contemporary society to be indifferent to these allegations? Does our society seek to condemn the homophobic attitudes as "wrong-thinking"? Recent reforms which aim to provide similar citizenship status and rights for gays suggest that today's pluralistic society expects a more tolerant attitude to these imputations.

\section{Out of Step with the Aspirational Values of Today's Pluralistic Society and Recent Gay Law Reform}

The application of the test by the courts is out of step with the aspirations of today's contemporary, pluralistic society. MacDougall says "the resort to any community standards to judge the 'acceptability' of the term homosexual fits uncomfortably in the inclusive-accommodative society that [our country] strives to be". ${ }^{123}$ Times have changed and so must the courts' response to imputations of gayness. The right-thinking person standard expresses a contemporary view that cannot ignore the changes in community attitudes and aspirations. The legal frameworks in AngloCommonwealth jurisdictions are now more inclusive towards gays: gays are accorded similar rights to straights and the State actively discourages discrimination against gays. The reform of the legal framework applying to gays now makes the conclusion that a person's reputation is tarnished by an imputation of gayness unsustainable. ${ }^{124}$

122 John Fairfax $v$ Rivkin, above 91, para 40 Kirby J.

123 MacDougall, above $\mathrm{n} 14,227$. He speaks of Canadian society but his remarks seem equally applicable to other Anglo-Commonwealth jurisdictions.

124 Fogle recognises there may be problems in using legislation to determine community attitudes or aspirations, particularly where there is an absence of relevant laws or the laws are contradictory, although ultimately he concludes these potential limitations are outweighed by the advantages of doing so: Randy Fogle "Is Calling Someone "Gay" Defamatory?: The Meaning of Reputation, Community Mores, Gay Rights, and Free Speech" (1993) Law \& Sexuality 165, 187. McNamara makes a similar point expressing concern that laws may be too uncertain to be a clear "external indicator of community attitudes", 
The way in which the law's treatment of gays has changed can be divided into two distinct groups, each with different implications: first, the decriminalisation of homosexuality and, second, equality rights such as the prohibition of discrimination on the basis of sexual orientation and relationship equality.

Where homosexuality or buggery is a crime, there is a much stronger case for such allegations being defamatory. Indeed, one alternative manifestation of the defamatory meaning test focuses on criminality. One of the specific defamatory situations Lord Sumner had in mind in Jones $v$ Jones was "when the words spoken impute a crime punishable with imprisonment". ${ }^{125}$ Brown also notes that a large number of defamation cases deal with allegations of criminality and it is sufficient that the words suggest a person is guilty of acts constituting a crime. ${ }^{126}$ The earlier cases (or cases in jurisdictions that still criminalise homosexuality) that find that imputations of gayness are defamatory can be seen in this light. The defamatory meaning could arise directly from the commission of a crime or, more generally, from the criminality being a proxy for moral condemnation of the activity by society.

The decriminalisation of homosexuality was an essential - but not necessarily determinative step towards taking the sting out of gay imputations. The qualification is perhaps best illustrated by looking at the catch-cry of the initial decriminalisation movement: as Canadian Prime Minster Pierre Trudeau said in 1969, "the state has no place in the bedrooms of the nation". ${ }^{127}$ Similar sentiments were expressed in the earlier Wolfenden Report; it took the position that there was a "sphere of private morality" that ought not be regulated by criminal law. ${ }^{128}$ This first phase of the gay rights movement was privacy based, led by "homophile" groups where the "social contract" or "Code of Silence"129 about homosexuality was still honoured. Where gays were victimised because of their sexuality, this drove the calls for decriminalisation and, to a certain extent, early equality rights. This privacy-based argument for decriminalisation was instrumental in the landmark Dudgeon $v$ United Kingdom decision of the European Court of Human Rights in which the Court concluded that the criminalisation of homosexual acts between consenting male adults breached the European

particularly where not all discriminatory aspects of legislation have been removed; however, ultimately he accepts reference to legislation is still "useful" in the process: McNamara, above n 100, 295.

125 Jones $v$ Jones [1916] 2 AC 481, 500 (HL) Lord Sumner.

126 Brown, above n 17, 73; Burrows and Cheer, above n 18, 15; Gatley, above n 17, para 3.2 .5

127 Donaldson, above n $42,84$.

128 Committee on Homosexual Offences and Prostitution The Wolfenden Report (Home Office, United Kingdom, 1957).

129 Larry Bush "Naming Gay Names" (27 April 1982) Village Voice; reprinted in Gross, above n 14, 177, and Richard Mohr, above n 14, 11. 
Convention on Human Rights. ${ }^{130}$ Importantly, though advocating decriminalisation, this argument "did not require people to abandon the view that homosexual acts were immoral."131 Therefore, despite decriminalisation, the moral condemnation of homosexuality could still provide a basis for defamation. ${ }^{132}$ In some respects, right-thinking people could perhaps be partly excused for their historical aberrations if the previous "social contract" or "Code of Silence" - which imply acknowledgement by gays of the societal dislike or shame associated with public exposure of homosexuality - is recognised.

More dominant today, however, is the minority rights model. Nowadays, instead of privacy, the buzz-word is "equality". The fight for equality - characterised by demands for relationship recognition, inclusion in broader societal events and positive support for separate gay organisations and institutions - took its lead from the earlier ethnic, cultural and women's civil rights movements. Necessarily involving the rejection of the social contract of invisibility, this model utilises "identity politics" for the benefit of gays and argues for equality with their straight counterparts. The minority rights approach creates analogies with other previously oppressed and underprivileged groups; the obvious analogies are today tantalising for the right-thinking members of society.

This second phase of law reform has reaped rewards for gays over a relatively short horizon. In 2000, Hunter noted that 30 years ago, "not a single political jurisdiction had a law against discrimination that was based on sexual orientation." 133 The change began with the enactment of anti-discrimination legislation protecting gays and lesbians: for example, in East Lansing, Michigan in 1972; Toronto, Ontario in 1973; Quebec in 1977; and Wisconsin in 1982. ${ }^{134}$ In New Zealand since 1994 sexual orientation has been included in the closed-list of prohibited grounds of discrimination in both the New Zealand Bill of Rights Act 1990 and Human Rights Act 1993. ${ }^{135}$ Anti-discrimination statutes protecting gays and lesbians in different spheres of activity have been

130 The Court ruled Dudgeon had "suffered and continue[d] to suffer an unjustified interference with his right to respect for his private life" which was a breach of Article 8 of the Convention: Dudgeon v United Kingdom (1981) EHRR 149, para 63 (ECHR).

131 Douglas Sanders Gays Without Borders? (Unpublished working paper, University of British Columbia, 2002) 13.

132 Decriminalisation in some cases may be specifically undertaken in a "morally neutral" manner. For example, the Prostitution Reform Act 2003 specifies that its purpose is to "decriminalise prostitution (while not endorsing or morally sanctioning prostitution or its use)."

133 Nan D Hunter "Sexuality and Civil Rights: Re-imagining Anti-Discrimination Laws" (2000) 17 NYL Sch J Hum Rts 565, 566.

134 Sanders, above n $131,15$.

135 New Zealand Bill of Rights Act 1990, s 19; Human Rights Act 1993, s 21(1)(m). 
implemented throughout Australia ${ }^{136}$ and Canada. ${ }^{137}$ The United Kingdom has some protection against discrimination on the basis of sexual orientation. ${ }^{138}$ Even the United States has a significant number of similar protections (although notably not at a federal level); over 12 states, one district, and over 120 municipal jurisdictions prohibit employment discrimination based on sexual orientation grounds. ${ }^{139}$

These anti-discrimination instruments are also augmented by the extensive moves to recognise same-sex relationships on the same or on a similar basis to opposite-sex relationships. In Canada, same-sex common law partners were recognised by the Supreme Court in $1999 ;{ }^{140}$ legislation was then introduced to amend various federal statutes that discriminated against same-sex couples. ${ }^{141}$ The right of same-sex couples to marry was recognised in various provinces in $2003^{142}$ and

136 In Australia, all the states and territories specifically prohibit discrimination based on sexuality or sexual orientation, as do federal laws. Racial Discrimination Act 1975 (Cth); Sex Discrimination Act 1984 (Cth); Disability Discrimination Act 1992 (Cth); Discrimination Act 1991 (ACT), s 7; Anti-Discrimination Act 1992 (NT), s 19; Anti-Discrimination Act 1977 (NSW), Part 4C; Anti-Discrimination Act 1991 (QLD), s 7; Equal Opportunity Act 1984 (SA), s 29; Anti-Discrimination Act 1998 (Tas), s 16; Equal Opportunity Act 1995 (Vic), s 6; Equal Opportunity Act 1984 (WA), s 35O.

137 In Canada, provincial and federal statutes prohibit discrimination based on sexual orientation (albeit that in Alberta the ground was "read-into" the anti-discrimination legislation by the Supreme Court in Vriend $v$ Alberta (1998) 156 DLR (4th) 385). In 1995, the Supreme Court of Canada ruled in Egan v Canada [1995] 2 SCR 513 that sexual orientation was analogous to the specific grounds enumerated in equality provision of the Charter of Rights and Freedoms and therefore the prohibition on discrimination also applies to sexual orientation.

138 The United Kingdom has incorporated the equality protections in Article 14 of the European Convention on Human Rights into domestic law through the Human Rights Act 1998 (UK). Although the Convention does not specifically mention "sexual orientation", it prohibits discrimination based on "sex" and the open-ended "and other status". This has been held to incorporate a prohibition of discrimination of the basis of sexual orientation: see Salgueiro da Silva Mouta v Portugal [2001] 1 FCR 653 (s 4, ECHR); Ghaidan v GodinMendoza [2004] 3 All ER 411 (HL); and Sandra Fredman Discrimination Law (Oxford University Press, Oxford, 2002) 73. However, discrimination on the basis of sexual orientation is not covered by the Sex Discrimination Act 1975 (UK): see Smith v Gardner Merchant Ltd [1998] 3 All ER 852 (CA), although discrimination on the basis of sexual orientation is addressed in the employment context by the Employment Equality (Sexual Orientation) Regulations 2003.

139 Hunter, above n 133, 566.

$140 M v H$ (1999) 171 DLR (4th) 596 (SCC).

141 Modernization of Benefits and Obligations Act C 2000 c 12.

142 Halpern v Canada (Attorney General) (2003) 225 DLR (4th) 529; EGALE Canada Inc v Canada (Attorney General) (2003) 107 CRR (2d) 1; Hendricks v Canada (Attorney General) (2004) 238 DLR (4th) 577; Dunbar v Yukon (2004) 122 CRR (2d) 149; Vogel v Canada (Attorney General) [2004] MJ No 418; Boutilier v Nova Scotia (Attorney General) [2004] NSJ No 357; W (N) v Canada (Attorney General) (2004) 246 DLR (4th) 345; and Harrison v Canada (Attorney General) (2005) NBQB 232. 
subsequently confirmed by federal legislation in $2005 .{ }^{143}$ New Zealand passed legislation in 2004 allowing same-sex couples to register their relationship as a civil union in a similar manner to married couples. ${ }^{144}$ The following year, the benefits, protections and responsibilities for married, civil union and de facto couples (both same-sex and opposite-sex) were largely harmonised. ${ }^{145}$ The United Kingdom has allowed same-sex couples to formally register their partnerships, giving them parity with married couples in various areas of the law. ${ }^{146}$ Many of the laws in Australian states recognise same-sex couples, although the recognition is piecemeal in places. ${ }^{147}$ Most recently, in 2006, the Australian Capital Territory passed legislation allowing same-sex couples to recognise their relationships as civil unions. ${ }^{148}$

In addition, criminal law now actively dissuades hostility towards gays through the recognition of hate crimes. Legislation in New Zealand, Australia and Canada explicitly provides that hostility or hatred towards gays as a motivating factor in crimes is to be treated as an aggravating favour in sentencing. ${ }^{149}$ Some jurisdictions also prohibit the vilification of gays or the incitement of hatred against gays. ${ }^{150}$

In the international context, Sanders' assessment was that: ${ }^{151}$

[B]y the end of the 20th century, concern with discrimination on the basis of sexual orientation had gained sufficient recognition in national legal systems, in the various European institutions, in actions of the United Nations Human Rights Committee, initiatives of the UN High Commissioner on Human Rights, and the work of important Non-Governmental Organisations, that it was unrealistic to say that the issue was not a part of a broad international human rights agenda.

143 Marriage for Civil Purposes Act C 2005 c 33.

144 Civil Union Act 2004.

145 Relationships (Statutory References) Act 2005 and companion legislation (amendments to 22 other statutes were separated out from the original Bill before the final reading and were passed separately).

146 Civil Partnership Act 2004 (UK).

147 Jenni Millbank and Kathy Sant "A Bride in Her Every-Gay Clothes: Same Sex Relationship Recognition in NSW" (2000) 22 Sydney LR 181, 199.

148 Civil Unions Act 2006 (ACT).

149 See for example Sentencing Act 2002, s 9(1)(h); Elisabeth McDonald "No Straight Answer: Homophobia as Both an Aggravating and Mitigating Factor in New Zealand Homicide Cases" (2006) 37 VUWLR 223; Criminal Code RS C 1985 c C-46, s 718.2(a)(i); Crimes (Sentencing Procedure) Act 1999 (NSW), s $21 \mathrm{~A}(2)(\mathrm{h})$.

150 See for example Anti-Discrimination Act 1977 (NSW), s 49ZT; Criminal Code (Can), s 318.

151 Sanders, above n 131, 2. 
Overall, the changes speak to a fundamental shift in the treatment of gays and their entitlement to citizenship on an equal basis with straights. Although the reforms are by no means complete in every aspect, the tide has turned significantly. The State, through this reformed legislative framework, sets an ideal of inclusion and equivalent treatment. Most of the prejudicial aspects of previous legislation have been eradicated. This State-endorsed legitimacy has important consequences for community standards. The effect on the "legitimacy" of minority groups is captured by Hunter: ${ }^{152}$

When legislatures extend the civil rights model to a new group, a powerful sense of social legitimacy is conferred. This sense of legitimacy develops, in part, because legislation can be enacted only after the group has reached a certain level of social acceptance. ... [It] implicitly communicates that the group has at least a toehold on legitimacy. ... The status gain for the disfavoured group comes from the withdrawal of the state's endorsement of discrimination.

But how far does this State-endorsed legitimacy go? Does it go so far as to mean that being described as gay no longer tarnishes a person's reputation? Hunter suggests that the civil rights model and anti-discrimination tools are "far from an instant panacea". ${ }^{153}$ Undoubtedly, consistent with the arguments of the realists, discrimination still exists despite the prohibitions. ${ }^{154}$ Millbank and Sant's assessment is that in Australia "[h]omophobia, discrimination and homophobic violence remain pervasive."155 Further, other pressing concerns such as gay and lesbian youth suicide and homelessness have yet to be addressed. ${ }^{156}$ Double standards still exist regarding the depiction of homosexuality in the popular media ${ }^{157}$ and public events. ${ }^{158}$ The treatment of gays by the judiciary

152 Hunter, above n 133, 566.

153 Hunter, above n 133, 566.

154 An example of recent overt discrimination in the public sphere is the refusal by municipalities in Canada to proclaim gay and lesbian pride days. See Okanagan Rainbow Coalition v Kelowna (City of) (2000) BCHRT 21; Oliver v Hamilton (City of) (1995) 24 CHRR D/298; Hudler v London (City of) (1997) 31 CHRR D/500 and Hill v Woodside (1998) 33 CHRR D/349.

155 Millbank and Sant, above n 147, 199.

156 Millbank and Sant, above n 147, 219.

157 For example, in a survey commissioned by the Broadcasting Standards Authority in New Zealand in 1999 on what the public considered acceptable in language and sexual behaviour for broadcast on television and radio concluded that the "portrayal of homosexuality encounters some reservations". In particular, "[s]cenarios depicting homosexual sexual activity sees half $(50.9 \%)$ of the respondents objecting where they had been more permissive of a similar scenario involving a heterosexual couple". See Broadcasting Standards Authority Consensus on Acceptability of Language and Sex in Broadcasting" (Wellington, 1999).

158 In New Zealand recently two women were threatened with eviction from a cricket match when they were shown kissing on the stadium big screen: see "Same-sex kisses just not cricket" (10 January 2006) The Dominion Post Wellington. 
still remains patchy; ${ }^{159}$ MacDougall complains that the rights of other groups still prevail over gay equality rights: "Sexual orientation is still not thought quite as worthy of protection as those other bases". ${ }^{160}$ As Millbank and Sant note, "formal legal equality [is not] a guarantee of the enjoyment of real equality in ... society." 161

The discussion of raw community views and treatment of gays, however, risks digressing too far into the trap of realism. Again, it must be emphasised that the legal test does not depend on unqualified objective standards. The test demands a higher standard; it speaks to the right-thinking members of society. But do these right-thinking people adopt the higher degree of tolerance championed by the pluralistic values commonplace in liberal, pluralistic societies? How quickly do they embrace the equality values underlying the anti-discrimination tools? There is an obvious tension between the transformative objectives of these tools and the community standards manifested in the right-thinking members of society test. An almost "chicken and egg" conundrum arises. As Guzman notes: "[There are] critical distinctions between law and community. On a temporal continuum, one is usually more or less progressive than the other. Indeed, rarely, if ever, are public policy and personal morality synchronous." 162

The point is that the need for anti-discrimination legislation arises, in part, because members of the community hold prejudicial and discriminatory views. These tools are intended to have instrumental effect, a point hinted at by Levine $\mathrm{J}$ in Kelly. ${ }^{163}$ However, the conclusion that the rightthinking members of society readily embrace these fundamental values seems unavoidable. Antidiscrimination is a fundamental tenet of contemporary liberal society. Its rationale lies in respect for human dignity. ${ }^{164}$ Protection of human dignity also underpins defamation law. ${ }^{165}$ These shared underpinnings suggest that it would be incongruous for right-thinking members of society to

159 For a discussion on the language used by the judiciary to describe gays and gay conduct, see Edward Clark "The Construction of Homosexuality in New Zealand Judicial Writing" (2006) 37 VUWLR 199.

160 Bruce MacDougall "A Respectful Distance: Appellate Courts Consider Religious Motivation of Public Figures in Homosexual Equality Discourse - The Cases of Chamberlain and Trinity Western University" (2002) 35 UBC L Rev 511, 537. His comments are principally directed at apparent "clashes" between gay equality rights and religious convictions in educational settings, namely Trinity Western University $v$ College of Teachers (British Columbia) [2001] 1 SCR 772 and Chamberlain v Surrey School District No 36 (2000) BCCA 519 (later overturned by the Supreme Court: see Chamberlain v Surrey School District No 36 [2002] SCJ No 87).

161 Millbank and Sant, above n 147, 219.

162 Guzman, above n 14, 1574.

163 Kelly, above n 95.

164 Fredman, above n 138, 17.

165 Fogle, above n 124, 171, drawing on Robert Post "The Social Foundations of Defamation Law: Reputation and the Constitution" (1986) 74 Cal L Rev 691. 
conclude that being characterised as belonging to a minority group would lower their opinion of a person. While decriminalisation of homosexuality may be morally-neutral, the promulgation of antidiscrimination instruments goes further and has as its very goal changing community behaviour and attitudes; by definition these instruments mark out prejudicial behaviour and attitudes as wrongthinking. For the right-thinking test to have any real difference from a test based on average community standards though, anti-discrimination instruments which seek to moderate community attitudes and demand tolerance cannot be ignored. As MacDougall says: ${ }^{166}$

Judges should reflect the principles, ideals, and aspirations of a society and not its lowest common denominator, especially in a context such as defamation. ... Canadian courts cannot protect individuals from discrimination on the basis of a particular characteristic (for example, sexual orientation) in a Charter of Rights or in a human rights context but accept in civil law the view of a majority of society (without even being polled) that a person with a characteristic is objectionable and being labelled as such is an 'injurious' thing.

The approach taken by Bell $\mathrm{J}$ in Rivkin v Amalgamated Television should be preferred over reference to raw community views. The fact that our societal and legal contours have changed and our community now aspires to end discrimination and prejudice against gays cannot continue to be ignored. The courts cannot simultaneously condemn discrimination against gays under antidiscrimination legislation and mete it out in defamation proceedings.

\section{CONCLUSION}

For many years the courts have accepted that unwanted imputations of gayness damage a person's reputation and entitle them to compensation through the tort of defamation. Despite one court ruling that this conclusion is no longer appropriate in today's society, there remains a reluctance on the part of the courts to definitively rule that the right-thinking person is now indifferent to imputations of gayness.

The conclusion that an imputation of gayness is defamatory remains problematic. It reinforces the view that gays are inferior and perpetuates homophobic attitudes towards gays. Undue emphasis is placed on the realist view of community attitudes towards gays, ignoring the public policy factors, which direct that prejudicial attitudes should not be reinforced by the tort of defamation. Society, through its laws, now aspires to equal citizenship for gays and equivalent treatment under the law. The aspirations of our pluralistic society will not be achieved if our courts continue to send the message that gays are less desirable members of society by concluding that imputations of gayness are defamatory.

166 MacDougall, above n 2, 227. 
